\title{
Antioxidant and hepatoprotective role of selenium against silver nanoparticles [Corrigendum]
}

Ansar S, Alshehri SM, Abudawood M, Hamed SS, Ahamad T. Antioxidant and hepatoprotective role of selenium against silver nanoparticles. Int J Nanomedicine. 2017;12:7789-7797.

On page 7796, the Acknowledgment is incorrect, it should have been:
The authors extend their appreciation to the Deanship of Scientific Research, King Saud University, for funding this work through the Undergraduate Student Research Support Program.
International Journal of Nanomedicine

\section{Publish your work in this journal}

The International Journal of Nanomedicine is an international, peerreviewed journal focusing on the application of nanotechnology in diagnostics, therapeutics, and drug delivery systems throughout the biomedical field. This journal is indexed on PubMed Central, MedLine, CAS, SciSearch ${ }^{\circledR}$, Current Contents ${ }^{\circledR} /$ Clinical Medicine,

\section{Dovepress}

Journal Citation Reports/Science Edition, EMBase, Scopus and the Elsevier Bibliographic databases. The manuscript management system is completely online and includes a very quick and fair peer-review system, which is all easy to use. Visit http://www.dovepress.com/ testimonials.php to read real quotes from published authors. 